\title{
Analysis the Oil Palm Land which can be Converted Into Paddy Fields in Irrigated Areas of Batang Tongar
}

\author{
Delvi Yanti", Eri Gas Ekaputra", and Roland Asmoro* \\ \# Faculty of Agricultural Technology, Andalas University, Indonesia \\ E-mail: delviyanti23@gmail.com
}

* Land and Water Resources Technique Laboratory, Faculty of Agricultural Technology, Andalas University, Indonesia

\begin{abstract}
An increasing number of shift functions of agricultural land into non-farming land, as well as the increasing development of the palm oil plantation area makes food program resilience increasingly difficult to be realized. Fields shift function also occurs in West Pasaman, which is still producing paddy fields converted into plantation. This research aims to analyze the oil palm land which can be converted into paddy fields. The confirmation of oil palm land which can be converted into paddy fields performed by some indicator, such as commitment, physical condition, the range of irrigation water, institutional and the width of the area. Based on the results of the analysis, the recommended oil palm area that can be converted into paddy fields in irrigated areas of Batang Tongar is 2.451 ha $(73 \%)$ and not recommended area is 540 ha $(27 \%)$. The unrecommended area caused by uncommitment farmer who change their oil palm area in paddy field and the farmer field which is irrigated in damaged condition so the water cannot be flow into the field.
\end{abstract}

Keywords - field potential; area convertion; Batang Tongar irrigation

\section{INTRODUCTION}

Food security is one of the determining factors in a country's national stability, both in the field of economic, social, political and security, so that food security has become a major program in agricultural development today and the future. Government programs as expressed by President Susilo Bambang Yudhoyono (SBY) to return to the farm, as one of the national target of 10 million tons of rice surplus in 2014, to put back the basics of a solid agricultural economic development.

Indonesia's food needs from year to year, increasing along with Indonesian population, while the farmland that produces food stuffs continued to diminish. An increasing number of changing functions of agricultural land into a residential area and shops or offices as well as the increasing extents the development of palm oil plantations making the food security program is increasingly difficult to be realized. Rapid development in various sectors has been pushing the function control changing the occurrence of agricultural land which occurred mostly in irrigated paddy fields. In Java, the paddy fields over the function between the years 1999 to 2002 reached 167.150 Ha, and outside Java 396.009 Ha [1].

Problems of land conversion almost never got the full attention of the Government. In fact, land conversion becomes the main problems that can affect the availability of the agriculture production. In 2015, the population of Indonesia is expected to reach 250 million people with food needs 35,123 million tons of rice. The year 2020 is estimated to need 9.3 million acres of rice paddies to full fill the needs of national rice. Now a days, the current extensive rice is only 8, 11 million hectares. From year to year rather than an expansion takes place, but increasingly extensive rice field shrunk [2].

This paddy field shrinkage also occurs in West Pasaman, which is being productive paddy fields converted into plantations. Paddy fields decreasing can be seen from the results in West Pasaman rice production that can only be used to full fill the needs of people's rice for 2 months. The changing of land using is caused by the high economic value of crops such as oil palm plantations. By planting oil palm plants that have high economical worth, farmers get a bigger profit than planting rice so give influence on the growth of the economy people of West Pasaman.

An increase in people's income in the field of palm oil plantations is dependent upon the age of Palm plants. Palm oil on the productive age $(\leqslant 20$ years) will provide more results than palm oil, which in not productive age $(>20$ years). Palm oil plantations that already entered is not productive (old) so it needs to be rejuvenated (re-planting). 
Because of the cost to do the rejuvenation, the solution is to turn their community livelihood gradually from palm oil planters into rice paddy farmers. Society's livelihood change is supported by the existence of the irrigation potential that has been built in district Pasaman, the Irrigation Area of Batang Tongar [3]. By the change of community livelihood to farmers' fields, the area of paddy fields in West Pasaman can be added up. The increasing of paddy fields capacious is supported by technical irrigation could be the object for national food security realization.

The purpose of this research is to analyze the oil palm land which can be converted into paddy fields based on indicators of land which can be converted into paddy fields.

\section{RESEARCH METHODS}

\section{A. Time and Location Research}

The research was carried out in August to October 2013. The location of the research is an irrigation area in Batang Tongar, sub district Pasaman, district West Pasaman, West Sumatra.

\section{B. Materials and Tools}

The materials and tools used in this research are: GPS, Microsoft Office Excel Software, Arc GIS Software 9.3, Administrative Map of West Pasaman (1: 250,000 scale, source: Bakosurtanal 2009), West Pasaman District land use Map (scale 1: 150000, source: Bakosurtanal 2011), a Batang Bongar irrigation network map (scale 1: 60,000, primary data sources: GPS).

\section{Research Procedure}

Before the irrigation network of Batang Tongar built, most areas of the West Pasaman district are a paddy land which water taken from Pasaman river. Because of people or farmers who plant rice, the Government built the technical irrigation of Batang Tongar in Pasaman sub district to full fill the water needs of crops of rice.

The development of palm oil commodity in West Pasaman making people or farmers who are in the area of Batang Tongar irrigation tempted to plant oil palm plants. This condition makes most of the rice farmers in irrigation area of Batang Tongar choose to switch into oil palm planters. The improvement of the management system by the related institutions make people want to plant rice back, due to the using of non-excellent seed palm oil, proximate distance of the plant and palm oil which is entered not productive age. So the society or the farmers need big cost to do oil palm plant rejuvenation.

The required data based on indicators of land which can be converted into oil palm land is:

\section{1) Farmer Commitments Data}

According to [3] the commitment of farmers can be grouped as follows: (1). Have no commitment (the value is 25 ), when farmers or groups of farmers did not switch to the paddy land (irrigated agricultural land). (2). Less committed (the value is 50), when paddy fields were not a priority of farmers, but there is still a desire to grow the rice plant, farmers do not have the commitment to make their land into rice paddies, if water is available in the irrigation channels.(3) Commitment (the value is 75), if there is a guarantee of irrigation water (water is available) then the farmer makes their land into irrigated rice fields. (4) Fully committed (the value is 100), if the guarantee of irrigation water (water is available) then the farmer promised to make its land into irrigated rice fields and proved by the MoU.

\section{2) The physical condition of the Irrigation Network Data}

According to [3], the physical condition of the irrigation networks can be classified based on the following criteria: (1) Heavily damaged (quality value is 25), when the irrigation network is not worth it anymore to use and the efficiency less than $25 \%$. At the level of this damage, farmers or groups of farmers can no longer fix. (2) Moderate damage (quality value is 50), when the damage has affected the efficiency and the flow rate of discharge is $25-50 \%$. At the level of this damage, farmers or groups of farmers can still improve. (3) Lightly Damaged (quality value is 75), when the damage does not affect the flow rate and large discharge efficiency is $50 \%-75 \%$ and farmers not affected against such damage. (4) Good (quality value is 100), if the conditions are good, there is no infrastructure that affects the water flow rate and large discharge efficiency of $75 \%$.

\section{3) Irrigation Water Range Data}

According to [3], networking ability to irrigate agricultural areas can be classified based on the following criteria: (1) Unaffordable (quality value is 25), if the land is already 3 years never get irrigation water. (2) Less (quality value is 50), when the irrigation water is not available in a few months. (3) Moderate (quality value is 75), where irrigation water is available throughout the year but sometimes has less amounts. (4) Great (quality value is 100), where irrigation water is available in the channels throughout the year.

\section{4) Farmer Institutional Data}

Based on the regulation of the Minister of Settlement and Regional Infrastructure on 2004, ranking participation of P3A/GP3A/IP3A can be grouped into 4. A division of the farmer's group participation rates can be seen in table 2 . The value given to each of the farmers group participation rates as follows: (1) Beginner (quality value is 25); (2) Associate (quality value is 50); (3) Advanced (quality value is 75); (4) Standalone (quality value is 100 )

\section{5) Land Range Data}

Ekaputra [3] say palm oil plantation land area that can be converted into paddy fields can be grouped according to the level of its range: (1) Small (quality value is 25), when the converted land is smaller than $25 \mathrm{Ha}$. (2) Enough (quality value is 50), when the converted land is $25-50 \mathrm{Ha}$. (3) Moderate (quality value is 75), when the converted land is $50-75 \mathrm{Ha}$. (4) Large (quality value is 100), when the converted land is more than $75 \mathrm{Ha}$.

\section{Data Analysis}

Determining of oil palm land which can be converted into paddy fields is performed by value weighting of indicators of land. The value of each indicator is presented in Table 1 . 
TABLE1.

PADDY FIELD POTENTIAL RATING

\begin{tabular}{|c|l|c|}
\hline Priority & Indicator & Value (\%) \\
\hline 1 & Commitment & 30 \\
\hline 2 & Physical Condition & 25 \\
\hline 3 & Range of Water Irrigation & 20 \\
\hline 4 & Institution & 15 \\
\hline 5 & Field Range & 10 \\
\hline \multicolumn{2}{|l|}{ Total Weight Value } & 100 \\
\hline
\end{tabular}

Source : [3]

The percentage of the value can be sum up with formula:

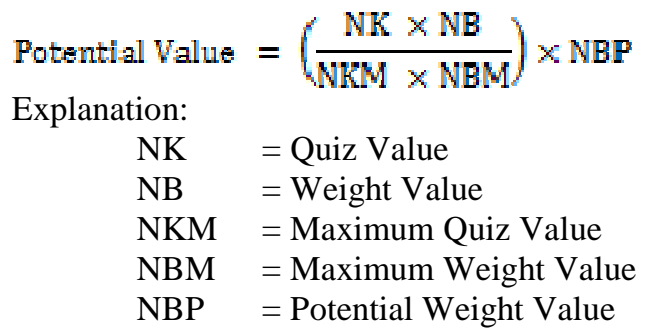

From Table 1, could be characterized farmland that can potentially be made based on the total value of wetland owned weights.

1. Not recommended, if the total value $<20$

2. Less Potential, if total value $20-40$

3. Quite potential, if the total value $40-60$

4. Potentially, if the total value $60-80$

5. Very Potential, if the total value $>80$

\section{RESULTS AND DISCUSSION}

\section{A. Description of Research Location}

The irrigated area is located in the Batang Tongar Pasaman sub district, West Pasaman district, West Sumatera Province and at 0'3'30 "- 0' 9'30" NL and 99'46'30 "99'53'30 EL. Batang Tongar irrigation is sourced from the Pasaman river running through the West Pasaman district. Area irrigated by Batang Tongar irrigation is $\pm 6644 \mathrm{Ha}$. In the irrigated area of the Batang Tongar, there are 41 farmer groups that utilize this irrigation water.

The Batang Togar irrigation area consists of 2.992 Ha oil palm, $73 \mathrm{Ha}$ of land/open moorland, $679 \mathrm{Ha}$ paddy land, $1.972 \mathrm{Ha}$ corn/vegetable farm, $697 \mathrm{Ha}$ settlement residentsand $588 \mathrm{Ha}$ land scrub/garden mix. The Batang Tongar irrigation composed mostly of coconut farm, while the small farm is paddy field.

\section{B. Oil Palm Land Indicators Which Can be converted into Paddy Fields}

\section{1) Commitments}

The commitment has the most value of all indicators. From the results of the interview with the head of each group of farmers (the respondents), there is a group of farmers who want to revamp the coconut over land into paddy fields and others do not want to change over their land. Farmers' desires to make a change in their land are presented in Figure 1.
Based on the indicator of commitment of farmers as much as $53.7 \%$ (there is commitment and fully committed) want to change over their land into paddy fields. Based on the results of the interviews with farmers, farmers' desire to change over its land into paddy fields due to several factors, among others: (1) Palm oil price which is cheap makes farmers' income decreases, so that farmers find it more profitable in their lands if planted with rice. (2) A farm which is owned by a farmer near the irrigation line that can full fill the water needs of crops of rice.

Farmers who are not committed to turning over its land into rice fields caused by: (1) Oil Palm farmers feel a great advantage compared to plant rice. (2) By planting oil palm will be a bit of work compared to planting rice is done per growing season. (3) Land owned by farmers ' lack of water, so it is not able to meet the water needs of crops of rice.

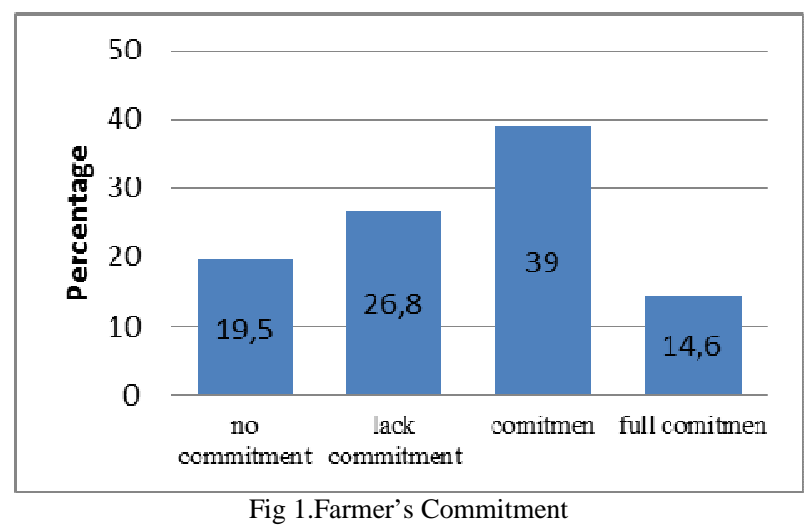

2) The Physical Condition Of The Irrigation Network

Government efforts to achieve the objectives in the production of rice by intensification of rice production and other food plants has been done by applying new technologies and land potential utilization to increase the production. To achieve the goal, the Government has invested in the development and rehabilitation of irrigation networks, construction of irrigation management and the provision of modern tools of production [4].

The physical state of the irrigation network and good tools of production can become advocates for expansion of paddy fields because it can transmit water to meet the water needs of crops of rice. From the results of the interview with the head of each group of farmers (the respondent), a Batang Tongar irrigation network through the region farmers' group has suffered heavy damage, moderate damage and light damage. Batang Tongar irrigation network conditions are presented in Figure 2.

An irrigation network of Batang Tongar is not it good condition (light and medium damage). Based on the results of the interviews to farmers and field observations on bad conditions of Batang Tongar irrigation network rated by farmers due to several factors, including: (1) The physical condition of the irrigation network through the land of farmers having leaks and damage to the water door. (2) Less caring of irrigation network made the buildup of junk and the number of plants that grow on the channels that impede water flow. 


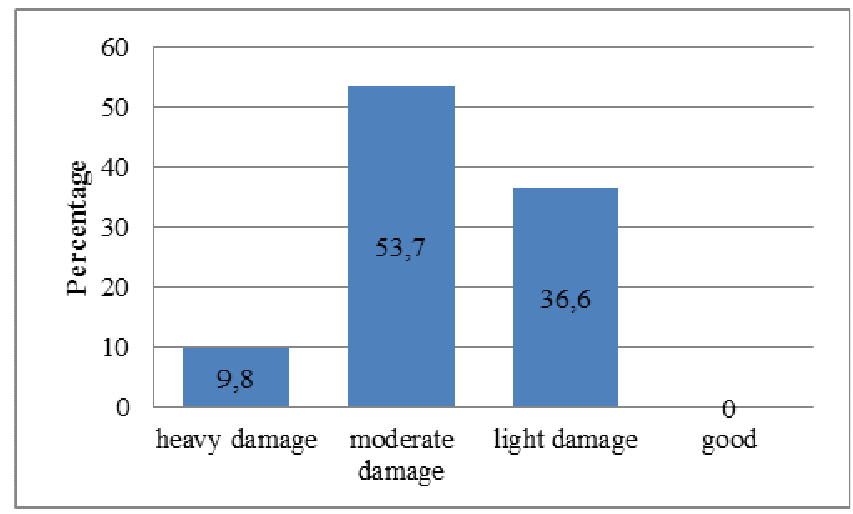

Fig 2. Physical Condition of Irrigation Network

Whereas in the irrigation channels occurred in heavily damages, due to the land at the base of the channel eroded by water that break down the channels and building irrigation. Farmers who land traversed a severely damaged irrigation network; perform repairs using wood to expedite the flow. In this state, the Batang Tongar irrigation network was still able to meet the water needs of crops of rice in most of the farmers' group.

\section{3) The Range of Irrigation Water}

Basically, the water needs to be regulated so can give the proper amount to the land and on time in order to provide the water supply for irrigation have significant aspect in rice production due to excellent seeds, fertilizer and good farming can provide the best result if it has enough irrigation available and the granting of water can be adjusted to the needs of the plant. Besides, it is also expanding the acreage of crops, increase the number of plants per year and increase productivity per hectare of land [5].

The irrigation network's ability to supply water to the rice plant needs also should be considered to note the change of paddy fields. From the results of the interview with the head of each group of farmers (the respondents), there is a group of farmers that are not affordable, affordable, a little less affordable and unaffordable by Batang Tongar irrigation. The range of irrigation water in the region of Batang Tongar irrigation is presented in Figure 3.

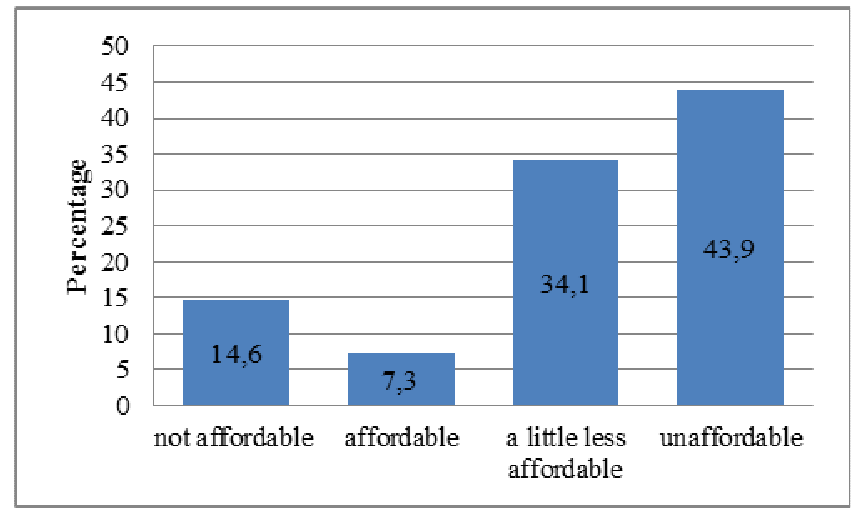

Fig 3.The Range of Irrigation Water

From the range indicator of the irrigation water as much as $78 \%$ of land farmers' groups(standard and good) in the area of Batang Tongar irrigation get water from Batang Tongar irrigation.
From the observations in the field, the Tongar river flow is greater in the rainy season or the dry season, making the water that flows on the Batang Tongar irrigation network is persistent or no less. The amount of water flowing in a channel makes land farmers who reside around the channel gets the water and has no shortage of water. The ability of water irrigation flow through the land of farmers who were around irrigation canals is good.

\section{4) Institutional}

According to government regulations about irrigation No. 20 year 2006, Water Users' Farmers Associations are the institutions which manage the irrigation water into the place for water user's farmers in an area of irrigation formed by water users' farmers themselves democratically, including local agency management of irrigation. With any place or gathering of farmers in an area helps to settle water utilization irrigation settings properly. In addition to this institutional, it can also specify the schedule of planting farmers to reduce the risk of water shortage for rice plant. Institutional farmer groups are presented in Figure 4.

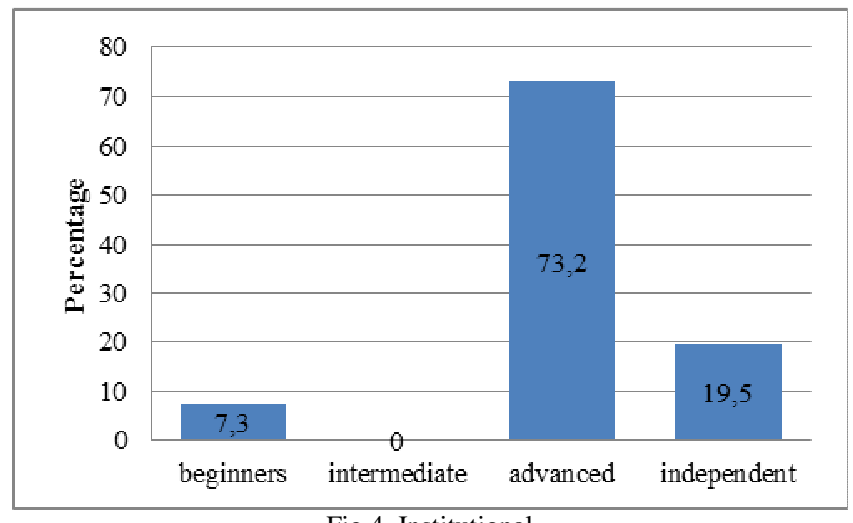

Fig 4. Institutional

Farmers who incorporated into upstart's farmer groups have long been inactive or have no activity. The activities of this group of farmers area a standstill since the farmers plant oil palm in their land, so there is no longer a regular schedule of Assembly, dues and deliberations within the group. Farmers' groups incorporated into advanced and standalone is a group of farmers who have a regular schedule for the Assembly and the arranged. Farmers' groups incorporated into advanced, because the farmer groups still have a regular schedule to assemble, but only 3-4 times a year and members who attended; fewer than half the members of the group.

Farmers' groups whom belonging to the self-supporting farmer groups, having a regular schedule for the Assembly and the arranged is 1 times in 1 month. In addition to the schedule, a farmer group members who are present in the meeting is more than half the total membership of the farmers group.

\section{5) Land Area}

According to [6] land ownership/status of the possession of the land is defined as land occupied or owned by individuals, groups of persons or institutions/ organizations. This property is generally formally proved by the certificates of ownership of land issued by the Government. In the 
management of agricultural land, especially agricultural land of rice fields, it is not a certain agricultural production with a high agricultural output caused by the vast land. In modern farming sometimes farmers do not have to have land can cultivate the land itself but in other ways.

Land area owned by the farmers incorporated into farmer groups in the area that can be converted into irrigated rice fields provide influence on increased the production of rice. The land area farmers' group is presented in Figure 5.

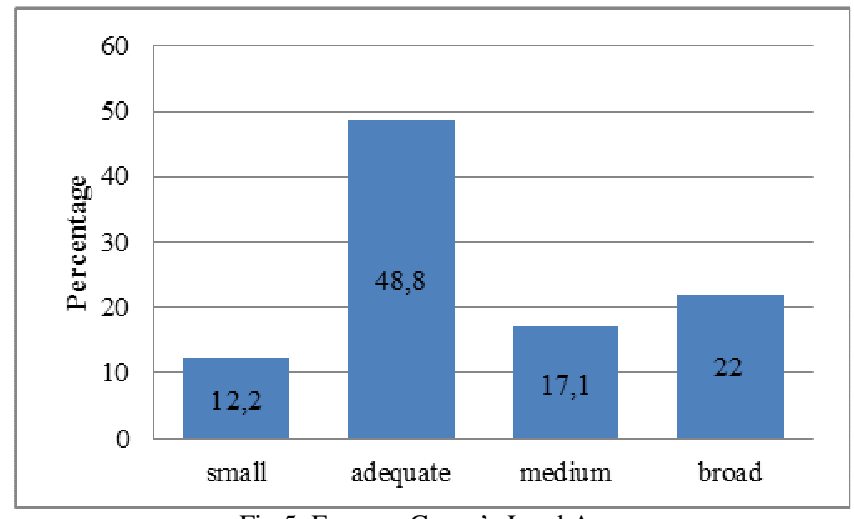

Fig 5. Farmers Group's Land Area

Based on the results of the interviews with farmers, farmer groups, which have a total area of land on the small category and quite extensive land ownership status in the area of irrigation Batang Tongar is the owner and tenants, so farmers have the desire to transform the land into a land of the oil palm. Whereas, the land which grouped into the medium category and large, its ownership status is the owner. In general, the land was given credence to other people to take care of the plants.

\section{Analysis Of Oil Palm Land Potential That Can Be Converted Into Paddy Fields}

From the 41 farmer groups there are $7.3 \%$, a very potent farmers' group, $43,9 \%$ farmer groups quite potentially, $22 \%$ of the potential farmers' group, 19.5 is less potent and $7.3 \%$ farmers groups are not recommended over their palm oil and converted into paddy fields. From this result, as many as $73,2 \%$ farmer groups (very potential, quite potential and potential) wanted to plant rice. Total area of the land the farmers' group that can and cannot be converted into paddy fields can be seen in Table 2 .

TABLE II

BOARD POTENTIAL LAND FOR RICE PADDY

\begin{tabular}{|c|c|}
\hline Explanation & Area (Ha) \\
\hline Very Potential & 94 \\
\hline Quite Potential & 1330 \\
\hline Potential & 1028 \\
\hline Less Potential & 520 \\
\hline Not Recommended & 20 \\
\hline
\end{tabular}

From Table 2, it is recommended that potential land for rice paddies covering an area of $2451 \mathrm{Ha}$ and not potentially covering an area of $540 \mathrm{Ha}$ of irrigation area in the Batang Tongar. With the area which is recommended to be used as a rice field can improve and meet West Pasaman rice needs. On paddy fields that exist at the moment of the $679 \mathrm{Ha}$ will produce rice as much as 3,395 tons. While in the land of recommended $2.451 \mathrm{Ha}$ will produce rice as much as 12.255 tons. From these results, can be compared between the production of rice in the current paddy fields and paddy fields which is recommended, then the rice production will be increased by $361 \%$.

Some of the land that could potentially become a rice field soil analysis has been done by determining $\mathrm{pH}$, content of aluminium ( $\mathrm{Al}$ ) and iron ( $\mathrm{Fe})$. Soil sampling was carried out on oil palm land $25-30$ years aged. Soil analysis results are presented in Table 3

TABLE III

SOIL ANALYSIS OUTPUT

\begin{tabular}{|c|c|c|c|}
\hline Sample & pH read & Al-dd (me/100g) & Fe-dd (me/100g) \\
\hline L1 & 6,63 & 0,00 & 0,30 \\
\hline L2 & 6,34 & 1,98 & 0,29 \\
\hline L3 & 6,81 & 0,00 & 0,39 \\
\hline
\end{tabular}

Based on soil properties and the range of nutrient elements criteria in soil in general, a layer of soil samples L1 has a neutral $\mathrm{pH}$, the very low content of Aland low Fe content. The sample L2 has a $\mathrm{pH}$ somewhat acid; very low content of $\mathrm{Al}$ and low Fe content. In a sample of the L3 has $\mathrm{pH}$ neutral, very low content of $\mathrm{Al}$ and low Fe content. From these results can be said that the oil palm land potentially can be used as a rice field because $\mathrm{Al}$ and $\mathrm{Fe}$ content were low so no poisonous for the plant. Plant poisoning can be defined as a decreased potential for growing the crop production and components.

Based on the results of the interviews to farmers and direct observation in the field the breadth of potential land for paddy fields in the area of Batang Tongar irrigation is caused by several factors, such as: (1) The farmers convinced by planting rice will be more profitable than oil palm planting because the price of palm oil is low. (2) Strategic land planted to rice that is located in the area of the technical irrigation. (3) Guaranteed water needs in the Batang Tongar irrigation if it managed properly. (4) With planting rice, people do not spend money again to buy rice because rice is the primary food of the community of West Pasaman. (5) Oil palm land which is far away from the path of farming make farmers pay extra to transport his crop, so that adds to the cost of production.

\section{CONCLUSIONS}

Based on the results of studies on land potential analysis of palm oil that can be converted into paddy fields in irrigation area of Batang Tongar, then the number of farmer groups that we are recommended to provide paddy fields as many as $73 \%$ with $2.451 \mathrm{Ha}$ area and who are not recommended for paddy fields as much as $27 \%$ with a total area $540 \mathrm{Ha}$. Fields which is not recommended due to the presence of farmers who have no commitment to change over its land into rice paddies and the land crossed by damaged irrigation networks causing the water does not flow into the land of farmers. 
Advice that can be given is the role of the Government should be state against fields that is not recommended as convincing farmers to plant rice more profitable and make improvements to the irrigation water network can flow on land the farmers. Next on, the recommended land should be realized so the recommended land can be turned into paddy fields and can increase the production of rice in West Pasaman.

\section{REFERENCES}

[1] Puslitbangtanak, 2005. A Century of Indonesian Soil Research Institution Progress 1905-2005.

[2] Suswono. 2013. Palm Oil Land is Bigger Than Paddy Field]. www.mediaperkebunan.net. 25 March 2013
[3] Ekaputra, Eri Gas. 2012. The Final Report Of Community Empowerment Facilitation Activities On The Management Of Water Resources In BatangTongar Irrigation Region (To Support The Activities Of Revitalization In BatangTongar Returned As Irrigated Rice Farmland) West Pasaman District. Padang.

[4] Hamdani. 1993. Prospects Utilization Irrigation Riam Kanan for Food Agriculture Development in South Kalimantan. Thesis S2. PPS-UGM Yogyakarta.

[5] Suparmoko. 1980. The Development of Irrigation In Food Strategy. Prisma No. 10 hal.37-47. LP3ES. Jakarta

[6] Pakpahanet al. 1992. Institutional Land and Soil and Water Conservation. Agricultural Research Center. 